Sea wall or sea front? Looking at engineering for Flood and Coastal Erosion Risk Management through different eyes

J. Simm

Reproduced from:

Flood Risk Management - Research and Practice Proceedings of FLOODrisk 2008

Keble College, Oxford, UK

30 September to 2 October 2008 


\title{
Sea wall or sea front? Looking at engineering for Flood and Coastal Erosion Risk Management through different eyes
}

\author{
J. Simm \\ University of Nottingham, Nottingham, UK \\ HR Wallingford, Wallingford, UK
}

\begin{abstract}
The UK Performance-based Asset Management System (PAMS) has developed a new process for assessing the condition of Flood and Coastal Erosion Risk Management (FCERM) assets in relation to their likely engineering performance (Simm et al, 2006). It is now being recognised that, in addition to their FCERM utility, assets offer significant amenity and aesthetic value. Where there is appropriate stewardship by landowners and other community stakeholders working in partnership, this can assist in social coherence by offering part of a 'realm of significance' for place-based communities. The paper draws on literature and on interviews conducted by the author with FCERM practitioners and with community members and activists. It concludes that the social performance of the assets can be understood within a broad theoretical framework of Order, Imagination and Justice (Gorringe, 2002), whilst reflecting Vitruvius' architectural principles (strength, utility and beauty) and insights drawn from sociology, psychology and other disciplines.
\end{abstract}

\section{BACKGROUND}

The Environment Agency manage over 10,000 km of raised flood defence assets (embankments, walls and structures) in England and Wales. These assets are managed to targets that are expressed as a condition grade: a number between 1 (Very Good) and 5 (Very Poor) that is determined by visual inspection according to the Condition Assessment Manual (CAM). As part of the development of the Performance-based Asset Management System (PAMS), the visual inspection of these flood defence assets is being improved by more closely relating the assessment of their current condition to their likely performance. The improved Condition Indexing process still works with the 5 condition grades, but builds up the condition index of an asset from a combination of failure mode indices. These failure mode indices are in turn built up from a weighted combination of visually assessed performance features. The assessment of the performance features is guided by flow chart based question and answer responses.

When imagining the structure of the condition indexing, it was thought that the structural performance condition index might eventually be supplemented by other condition indices (e.g. safety, amenity, landscape), some of which will be of significant interest to local communities (Simm \& Samuels, 2006) This paper presents some preliminary thinking and research about the issues that social condition indices might need to embrace.

\section{POSSIBLE APPROACHES TO PHYSICAL ASSETS OFFERED BY SPECIALIST DISCIPLINES}

When seeking to find an approach that links FCERM assets to social issues, no one specialist discipline seems to offer a comprehensive answer, although many offer useful insights.

\subsection{Social science}

Within social science there are a wide range of underlying theories. These include those of the past century such as Marxism, feminism, functionalism, structuralism but also other theories which have been propounded more recently to reflect post-modern society. Unfortunately, as Bruno Latour (2005) argues, the role of 'objects' (in this case FCERM assets) in these theories propounded by 'sociologists of the social' tends to be quite limited, only recognising the involvement of objects in social accounts via the following three modes of existence (op cit, p. 84):

- "As a 'material infrastructure' that 'determines' social relations as in Marxian types of materialism - As a 'mirror' that simply 'reflects' social distinctions like in the critical sociologies of Pierre Bourdieu

- As a backdrop for the stage on which human social actors play the main roles like in Erving Goffman's interactionist accounts." 
In explaining the perspective of Actor-NetworkTheory, Latour $(2005$, p. 75$)$ argues that this is too narrow a viewpoint and that objects (such as FCERM assets) in addition to 'determining' and serving as a 'backdrop for human action' "might authorise, allow, afford, encourage, permit, suggest, influence, block, render possible, forbid and so on. It is reasonable to make objects participants in the course of action, even though objects help trace social connections only intermittently."

The five main situations (op. cit., pp. 80-82): identified by Latour in which the 'momentary visibility' of objects is clear enough to trace their social role are when:

- “innovations [are created] in the artisan's workshop, the engineers design department, the scientists laboratory, the marketer's trial panels, the user's home, and the many socio-technical controversies.'

- "implements are approached by users rendered ignorant and clumsy by distance - distance in time as in archaeology, distance in space as in ethnology, distance in skills as in learning."

- "'risky' objects [are involved in] accidents, breakdowns and strikes."

- "objects [are] brought back to light by using archives, documents, memoirs, museum collections, etc., to artificially produce through historians' accounts the state of crisis in which machines, devices and implements were born."

- "fiction [brings] - through the use of counterfactual history, thought experiments and 'scientifiction' - the solid objects of today into the fluid states where their connections with humans may make sense. Here again sociologists have a lot to learn from artists"

\subsection{Social geography}

As discussed above, although the social role of engineering objects has not really been explored in the literature, the contested topics of 'sense of place' and 'sense of community' have been examined by a number of writers in social geography, many making links between the two.

Diane Warburton (1998, p. 17), for example, argues that the notion of community has two elements: "one to do with relationships between people, and one to do with relationships between people and the place in which they are located. It is to do with a common feeling based on sharing a place which creates a particular type of [caring] relationship."

Many writers identify the decline of the significance of place to community as a result of industrialisation (Tönnies, 1963; Cohen, 1985; Delanty, 2003). However, Sennett (1998), amongst others, identifies a trend which may be re-invigorating the signifi- cance of place to community. He comments: "One of the unintended consequences of modern capitalism is that it has strengthened the value of place, arousing a longing for community. All the emotional conditions .... in the workplace animate that desire: the uncertainties of flexibility; the absence of deeply rooted trust and commitment; the superficiality of teamwork; most of all the spectre of failing to make something of oneself in the world, to 'get a life' through one's work. All these conditions impel people to look for some other sense of attachment and depth." (op. cit., p. 138). Creswell (2004, citing Agnew, 1987) gives three fundamental ways in which place is a 'meaningful location':

1. Location - the simple notion of 'where'

2. Locale - the material setting for social relations, or (Delanty, 2003) the 'container of community'.

3. Sense of place - the subjective and emotional attachment to place by people alluded to by Warburton and Sennett as discussed above.

Cresswell (2004) goes on to identify and compares aspects of place noticed by Harvey (1996) and Massey (1991). Harvey's reactionary sense of place is marked by

- A close connection between place and a singular form of identity.

- A desire to show how the place is authentically rooted in history.

- A need for a clear sense of boundaries around a place separating it from the world outside.

By contrast, Massey's (1997) progressive sense of place is marked by:

- Place as process.

- Place as defined by linkages to the outside.

- Place as site of multiple identities and histories.

- A uniqueness of place defined by its interactions.

Analysing the work of these two authors, Liepins (2000) comments "that 'community' and 'place' are two concepts that are constantly intertwined in highly complicated ways. Communities may not be primarily identified according to their coincidence with particular places ... Nevertheless, communities involve social relations that occur transiently or continually in both places and spaces."

\subsection{Community psychology}

The concept of the "psychological sense of community" was first postulated by Seymour Sarason (1974), who thereby initiated the study of community psychology. McMillan \& Chavis (1986), in their subsequent analysis of this concept, identified membership (i.e. 'belonging') as one of four key elements 
(the others being influence, integration and fulfilment of needs and shared emotional connection). Within membership they identified five component aspects, strongly linked to place, which "seem to fit together in a circular, self-reinforcing way, with all conditions having both causes and effects. [1] Boundaries provide the protection for intimacy. The [2] emotional safety that is the consequence of secure boundaries allows people to feel that there is a place for them in the community and that they belong. A [3] sense of belonging and identification facilitates the development of a [4] common symbol system, which defines the communities boundaries." Finally, "feelings of belonging and emotional safety lead to self-investment [5-personal investment] in the community, which has the consequence of giving a member the sense of having earned his or her membership."(McMillan \& Chavis, 1986, p. 15). Their discussion of boundaries and symbol systems for communities offered by place resonate with ideas discussed by social scientists (see e.g. Cohen, 1985).

Following McMillan and Chavis (1986), a rich literature has built up in this area, much of it with the aim of measuring Psychological Sense of Community (or Sense of Community Index, SCI). Since initial implementation, there has been considerable debate about the structure of the SCI and the factors or weightings that should be applied to the different components (Peterson et al, 2006; Tartaglia, 2006).

As an example, Puddifoot $(1995,1996)$ developed a multi-dimensional model of Community Identity, seeking to draw together aspects of Social Cohesion and Community Satisfaction into the SCI index being used by most authors and in doing so drew in such factors as:

- Locus-boundaries, physical features, social/cultural characteristics

- Distinctiveness

- Identification - affiliation/belonging/emotional connection to location

- Personal orientation

- Quality of community life

- Community functioning

\subsection{Landscape architecture}

A lot of work has been done at what could best be described as the 'landscape scale' of identifying and monitoring features of places. For example, landscape architect Anne Whiston Spirn (1998, pp. 54-77) identifies a number of genres that could be associated with landscapes: worship, memory, play, movement and meeting, production and waste, home and community. In a more formal way, these kinds of features are now being identified in the programme of Landscape Character Assessments which are being carried out across Great Britain. The LANDMAP ${ }^{1}$ GIS approach being adopted in Wales by the National Assembly (Scott, 2002) is different from the joint approach being adopted by Scottish Natural Heritage and Natural England for Scotland and England ${ }^{2}$ but the scale of features being assessed in both cases is generally larger than most FCERM assets. The Welsh approach divides the assessment into main categories of Cultural, Historical, Visual \& Sensory and Habitat, with 4 levels of classification, although classification down to Level 3 is all that is required by the Unitary Authorities. Interestingly, in the guidance on the assessment of cultural associations reflecting how a landscape may have shaped culture or vice versa, they distinguish between:

- Material expressions-where the landscape has been shaped by a particular cultural activity e.g. agriculture, industry

- Notional expressions - where the culture is embodied in the landscape through a sense of place, e.g. via communities, famous people or institutions.

- Recorded expressions - where the landscape has been recorded in a cultural medium, e.g. art, oral expression.

Sociologist Creswell (2004) points out that "Landscape is an intensely visual idea ... the viewer is outside of it. ... Places are very much things to be inside of." [i.e. to be lived in] (pp. 10-11). The current approach to Landscape Character Assessments seems to blur this distinction, but the point is still a valid one: the tourist experiences landscape as a kind of visual consumer whereas residents 'dwell in' a place. Each brings a different worldview to the same thing and probably experiences quite different feelings. However, Creswell's view may be over-simplified, because one of the reasons why residents may 'dwell' in a place is because they are also consumers, appreciating the aesthetic appeal of the place.

Much less work on landscape has been done to identify the value of features which can be expressed at a smaller scale, associated with the assets themselves. Pilot projects conducted by the Countryside Agency and Cheshire Landscape Trust (2005) describe some preliminary work on producing two combined Village Design and Parish Landscape Statements which were subsequently adopted as Supplementary Planning Guidance and some Statements based on this guidance are now beginning to emerge. Although it is not clear to what extent these have resolved the question of scale, an important lesson learnt (or confirmed) from these studies is the importance of seeing all community objectives in an integrated way. It is important, therefore, to appreciate that the social

${ }^{1}$ See http://landmap.ccw.gov.uk

${ }^{2}$ See http://www.landscapecharacter.org.uk 
role of management of FCERM assets must be seen within the broader context of all the objectives and aspirations of a local community and of all the assets available to them.

One of the challenges facing this work is to recognise that the desirability of assets and their significance will depend on the worldview (the Weltanschaunng) of the person concerned and will be affected by the circumstances or role in which they find themselves at a particular time (Checkland \& Scholes, 1990). Take concrete sea wall sweeping around a coastal bay, perhaps with an associated promenade and a set of timber groynes marching across the beach at regular intervals are very much part of the 'bigger' landscape. The issue that surrounds the landscape 'value' of these assets is firstly which of them should be present or absent in the first place. ECUS (2003), for example, argue against groyne fields, perceiving them as having adverse landscape and visual impact. However, if such structures are required, it is still important to consider detailed social value issues of whether the wall is suitable for sitting on, or whether the groynes are exposed sufficiently to provide shelter from the wind for sun-bathing, whilst not being so high as to completely dominate the beachscape. Local input could be important in influencing these design aspects.

\subsection{Architecture}

Moving from landscape architecture to architecture proper, the starting point for thinking about the relation between buildings and people has to be Vitruvius' classical threefold categorisation of firmitas, utilitas, and venustas commonly remembered in Sir Henry Wotton's (1568-1639) translation as "commodity, firmness and delight". Gwilt's (2007) translation the relevant extract from Marcus Vitruvius Pollio's De Architectura is:

"Architecture consists of three branches; namely, building, orientation, and mechanics. Building is divided into two parts. The first regulates the general plan of the walls of a city and its public buildings; the other relates to private buildings. Public buildings are for three purposes; defence, religion, and the security of the public. Buildings for defence are those walls, towers, and gates of a town, necessary for the continual shelter of its inhabitants against the attacks of an enemy. Those for the purposes of religion are the fanes and temples of the immortal gods. Those for public convenience are gates, fora or squares for market-places, baths, theatres, walks, and the like; which, being for public use, are placed in public situations, and should be arranged to as best to meet the convenience of the public.

All these should possess strength, utility, and beauty. Strength arises from carrying down the foundations to a good solid bottom, and from making a proper choice of materials without parsimony. Utility arises from a judicious distribution of the parts, so that their purposes be duly answered, and that each have its proper situation. Beauty is produced by the pleasing appearance and good taste of the whole, and by the dimensions of all the parts being duly proportioned to each other."

Leyland Roth (2007) expounds the details of how this characterization of architecture is viewed today, explaining that Vitruvius' categorisation has been challenged by architects over the years. In particular, as Roth (op. cit., p. 67) explains, "from 1910 to 1960 , Western architects and others around the world whom they influenced chose to believe that delight in architecture had no independent existence, that beauty resulted automatically through maximizing functionality and the expression of the structure. Advocates of what became known as International Modernism argued that the Vitruvian formula had forever been dispelled, so that commodity plus firmness equaled delight, or, as Bruno Taul wrote, architecture was the creation of "the perfect, and therefore the most beautiful, efficiency." Since about 1965, however, architects, critics and historians have reversed their position saying again that "there can be an independent quality of delight in architecture and that the most esteemed architecture endeavours to produce the greatest pleasure for the price, with function and durability being satisfied as well."

Perhaps Vitruvius categorization can be interpreted in the context of FCERM assets as follows:

- Firmitas (strength) expresses the functional value of the assets to deliver their principal engineering function, particularly in the extreme events for which they must necessarily be designed. Here communities are expected mainly to be concerned about the protection that the assets offer from flooding and erosion events, but clearly they will also want to be assured that the assets are also fit for purpose for any recreational or other social function.

- Utilitas (utility) relates to the features of the assets when being routinely used by the public in various ways. Here their amenity, health, safety etc will be important during regular use for walking, playing, relaxing etc. These may include some of those features which fall into sub-categories alluded to above such as quality of community life and community functioning (Puddifoot, 1995).

- Venustas (beauty) is taken to encompass all the positive symbolic meanings and other values which individuals and communities attach to the assets. Here a sub-categorisation following the work of the landscape characterisation in Wales alluded to above may be useful (Visual \& Sensory, Cultural, Historical, and Habitat): 
- Visual and Sensory can be taken to include all the visual, aural, sensual and olfactory aesthetic features of the assets,

- Cultural can be taken to include features which fall into sub-categories already alluded to above such as symbolic boundaries, emotional safety, and distinctiveness/familiarity leading to a sense of belonging and identification (Cohen, 1985; McMillan \& Chavis, 1986; Puddifoot, 1995).

- Historical can be taken to include both historical and archaeological associations.

- Habitat can be taken to include relevant socioecological associations.

\subsection{Built environment}

As landscape planning merges into architecture, the broader discipline of the Built Environment emerges, although the phrase suggests a greater degree of integrated thinking than may occur in reality and most of the thinking relates to buildings and their context rather than dealing with infrastructure like FCERM assets. Nonetheless, Bartuska (2007), in an introductory framework paper for an integrating textbook for students, identifies the following hierarchy of components of the built environment:

1. Products

2. Interiors

3. Structures

4. Landscapes

5. Cities

6. Regions

7. Earth

There is a strong focus in these categories on buildings rather than infrastructure, but there is no reason why the principle of a hierarchy of scales should not also hold good. In this respect, a classic example of an integrating approach across the built environment with an embedded hierarchy of scales would be the 'pattern language' developed by architect Christopher Alexander (1978). Alexander's book suggested a number of factors to the author which might be important. The resulting list of factors which emerged is loosely graded from features which might be viewed as being at 'landscape' scale down to a much finer level of detail:

- Physical community configuration

- Neighbourhood boundaries and gateways

- Road links and car parks

- Public transport

- Links to schools and education

- Links to shopping and commerce

- Crime mitigation

- Vertical and horizontal scale
- 'Sacred' sites - 'places that have come to symbolise the area and the people's roots there'

- Access to water and the attraction of the sea-side river front as a 'place to go'

- Promenade, with associated points of attraction at each end and clusters of eating places and small shops

- Arrangements to allow people to safely use (part of) the area at night

- Facilities for the old and disabled

- Facilities for children; adventure playgrounds

- Links to schools, colleges and universities

- Civic space linked back to the community

- Health \& safety

- Hard landscaping, pools, little man-made streams

- Green spaces and garden features, raised planted beds

- Pedestrian walkways and road crossings

- Cycle paths

- Small public squares and larger areas of common land.

- Public 'outdoor rooms'

- High places from which people can view the area

- Places to perform music etc from (Bandstands etc) linked to the promenade

- Sport's facilities

- Provision for animals and pets

- Places to sit and to sleep

- Walls suitable for sitting on

- Places for summer awnings to provide shade etc.

Alexander's more recent four volume work (Alexander, 2004) further develops his theory and practice, seeking to encourage implementation of 'living' systems for buildings and town plans, based on fifteen geometric properties which are also seen in nature. These patterns are: levels of scale, strong centres, boundaries, alternating repetition, positive space, good shape, local symmetries, deep interlock and ambiguity, contrast, gradients, roughness, echoes, the void, simplicity and inner calm, and not-separateness.

Alexander's work emphasizes the value of building and spaces which enhance our lives, emphasising the interplay between structure and space. The Commission for Architecture and the Built Environment (CABE, 2004) draw out the importance of properly designed and managed public space in delivering economic value, providing space for physical recreation, providing places for children to play and enjoy the natural environment, reducing crime, generating social cohesion, and supporting biodiversity. Bartuska (2007) also emphasises the significance of human needs and values in the built environment. Bartuska sees these as being linked to the hierarchy of human needs first proposed by psychologist Abraham Maslow. Maslow suggested that physiological needs for (1) physical survival (air water food, 
etc), (2) reproduction, and (3) security and bodily protection have to be met before people can have their psychological and social needs. In seeking to move forwards with the non-FCERM social value of assets, it is clearly important to make sure that people do not feel insecure to flooding or coastal erosion or that will preoccupy their concerns and actions.

\section{POSSIBLE APPROACHES OFFERED BY TWO CROSS-CUTTING DISCIPLINES}

With the diversity of potential approaches for identifying the social value of assets, it might be concluded that no one unifying approach is possible within a specialist discipline. For this reason, investigation has been made of the major cross-cutting disciplines of philosophy and theology.

\subsection{Philosophy}

One fundamental categorisation of features can be derived from that in metaphysics. It was the Greek Philosopher Aristotle (Edghill, 2007; Wickipedia, 2007a) that identified 10 categories of being, Notice that these are not descriptions as such of their substantial nature (weight, chemical, composition etc) but in the way every object may be apprehended by humans. In grammatical terms this view of objects can be seen as the ways in which they can be viewed as the subject or predicate of a proposition. Hence the categories became known as the praedicamenta.

Aristotle's ten categories, or classes, are:

1. Substance. That which can be said to be predicated of nothing nor be said to be within anything. These are subdivided into "primary substances" ("this particular man" or "that particular tree") and "secondary substances," which are universals. Hence, "Socrates" is a primary Substance, while "man" is a secondary substance.

2. Quantity. This is the spatial extension of an object.

3. Quality. This is a determination which characterizes the nature of an object.

4. Relation. This is the way in which one object may be related to another.

5. Place. Position in relation to the surrounding environment.

6. Time. Position in relation to the course of events.

7. Position. The examples Aristotle gives indicate that he meant a condition of rest resulting from an action: 'Lying', 'sitting'. Thus position may be taken as the end point for the corresponding action. The term is, however, frequently taken to mean the relative position of the parts of an object (usually a living object), given that the position of the parts is inseparable from the state of rest implied.

8. State. The examples Aristotle gives indicate that he meant a condition of rest resulting from an affection (i.e. being acted on): 'shod', 'armed'. The term is, however, frequently taken to mean the determination arising from the physical accoutrements of an object: one's shoes, one's arms, etc.

9. Action. The production of change in some other object.

10. Affection. The reception of change from some other object. It is also known as passivity. It is clear from the examples Aristotle gave for action and for affection that action is to affection as the active voice is to the passive. Thus for action he gave the example, 'to lance', 'to cauterize'; for affection, 'to be lanced', 'to be cauterized.' (Note: The term is frequently misinterpreted to mean a kind of emotion or passion.)

There is a significant difference between the first or fundamental category of substance and the subsequent categories. These latter categories are of interest to this research particularly in the emphasis on the relation between humans and objects (in this case, assets) or the interrelation between those objects (assets).

To understand the significance of these concepts today it is helpful to examine the way Aristotle's ideas have been taken up by more recent philosophers. Of particular interest are the ideas of the Martin Heidegger. To understand the way Heidegger (building on his predecessor, Husserl) interprets and extends Aristotle, it is necessary to start by developing a fundamental understanding of 'being' or 'to be'. Aristotle had identified (Inwood, 1997, p. 16-18) that saying something 'is' can have at least two meanings. Firstly that it exists (either actually or potentially). Secondly, it can mean that it 'is true', or 'is the case'. Heidegger describes these meanings respectively as: 'that'-being (the fact that something exists) and 'what'-being (what that thing is, equivalent to the 'substance' of Aristotle's first category). But Heidegger adds a third meaning, 'how'-being. This captures the idea of the 'mode, manner or type of an entity's being' (op cit, p. 17) and really embraces the remainder of Aristotle's ten categories. 'For example if we remain for a moment within the confines of Aristotle's categories, then we have, first, the fact that horses exist, secondly those features of horse that distinguish it from other animals and from other substances in general, and finally its mode of being' (op cit, pp. 17-18).

Heidegger's approach contrasts with that of phenomenologists such as Husserl who focused on the experience of seeing, e.g. a table, as an "extended object' as he walked around it, for example its 
different geometrical presentations. Heidegger's work on ontology offers a different approach or account of how we (subjectively) experience objects (op cit, pp. 33-35).

1. Our first perception, Heidegger argues, is to see them as objects of use, connected to human purposes. 'What is see is not just a table, but the table, the table in this room. The table is for writing on, or for eating at.' (op cit, p. 33).

2. Secondly, objects refer to each other and thus constitute a realm of significance, one which includes both the direct human environment (e.g. a workshop) in which we operate at any time and also the wider realm of our existence.

3. Thirdly, time and space are involved and Heidegger's idea of how we experience objects can be very approximately summarised as having three aspects:

- Spatial suitability of an object in itself and in its relationship with other objects and users ('Is the table in the right size and in the right place for our purposes. Is it big enough to seat the whole family for a meal? Is it too far from the light or from the bookcase for writing?')

- Spatial relations between objects expressed in terms of time. (The distance to the table is a few seconds. It is ten minutes walk to the town centre. Going to London will take two hours.)

- The relation of objects back to past events and to uses that will be made of them. (Past events might include the scratches the boys made on the table, the book he wrote at it. Its future significance might include, say, meals he is planning at the table.)

Heidegger does also point out that, in practice, these things are not continually noticed. The human is aware of them tacitly, but they are inconspicuous and unobtrusive. They are not focused on, probably because the objects in the living environment are known to refer to each other and constitute a realm or web of significance.

These categories and relationships are different from the firmitas, utilitas and venustas of Vitruvius. The emphasis on suitability for use by humans is clearly related to both firmitas and utilitas. Perhaps part of venustas involves the aesthetic relationship between objects and between the objects and the viewer; it certainly includes the temporal (historical) relationships. However, Heidegger's explicit articulation of the (firmitas and utilitas) spatial and temporal interrelationship between objects for use and with humans seems to be something new, although clearly architects would argue it is implicitly very much part of their thinking and practice.

\subsection{Theology}

One of the disadvantages of philosophy is that it often seeks to detach itself from human experience in order to seek a rather pure understanding of being and action, of space and time.

Some surprising help was therefore gained from theology. Not many theologians have teased out the significance of physical features for societies, although writers like Walter Brueggemann (2002) have started to draw out the interelation between land and faith in the context of Judaism and Christianity. Brueggemann (pp. 43-65) draws out the tension between a right acceptance of the responsibility of stewardship of land viewed as a gift against the temptation to a materialistic grasp and domination of it.

Gorringe appears to be the contemporary theologian that has wrestled most intensely with this issue in his theology of the built environment (Gorringe, 2002). Gorringe argues in his book for a "Trinitarian mapping of spatiality”, using keywords (op cit, p. 49) of Imagination, Order and Justice.

Evaluating this it seems clear that this framework has many resonances with approaches in the other disciplines and accounts described above, but has the advantage of being more comprehensive.

The idea of Order ('God the Creator ... brings order out of chaos') captures a strong theme in Vitruvius and architectural thinking, not least in order for structures to have appropriate strength (firmitas) and utility (utilitas). The concept of order can also be seen to embrace the of hierarchy, spatial interrelationship and appropriateness for use which have been seen to be so important by such diverse writers as Alexander (2004) and Bartuska 2007) and Heidegger (Inwood, 1997).

The idea of Imagination ('God the Holy Spirit ... is the inspirer of ... visions of a better human environment) captures the remaining Vitruvian principle of beauty (venustas) and a lot of the ideas embedded within landscape character assessment and what Alexander (2004) sees as 'natural' principles for architecture. It also embraces ideas of symbol and emotional attachment and the way that the coastal and river environment has inspired artists, poets and writers.

The idea of Justice ('God the Reconciler takes flesh in order to teach peace to the nations') is perhaps the key missing strand. Gorrigne is keen to emphasise that the Order he conceives is no 'Stalinist central planning', but one which emerges from a 'God who loves in freedom' and which is therefore much more akin to a consultative process (op cit, $\mathrm{p}$. 48). He recognizes that 'alienation, domination and reconciliation can all be and are expressed in the built environment.' The built environment should be the place 'where social justice is, quite literally, made concrete'(p. 49). It is not about avoiding difference 
and conflict, but harnessing it creatively in humility and hope.

\section{FRAMEWORK}

Building on Gorringe's ideas, the author has expressed this framework making use of the symbol of the Celtic Cross (Figure 1), appropriate given that it symbolises a holistic view of life (Silf, 2001, Bryce, 1995).

The vertical axis-mundi in Figure 1 indicates Order being achieved, simultaneously respecting general principles of engineering design and environmental management but mediating these into local solutions with due respect for the needs of local communities. The horizontal axis indicates the tension of achieving Social Justice, working through disagreement and conflict through engagement to bring reconciliation. The wheel or circle, traditionally representing glory or the spiritual dimension, indicates the Inspiration dimension, reflecting the aesthetic and intangible value associated with assets.

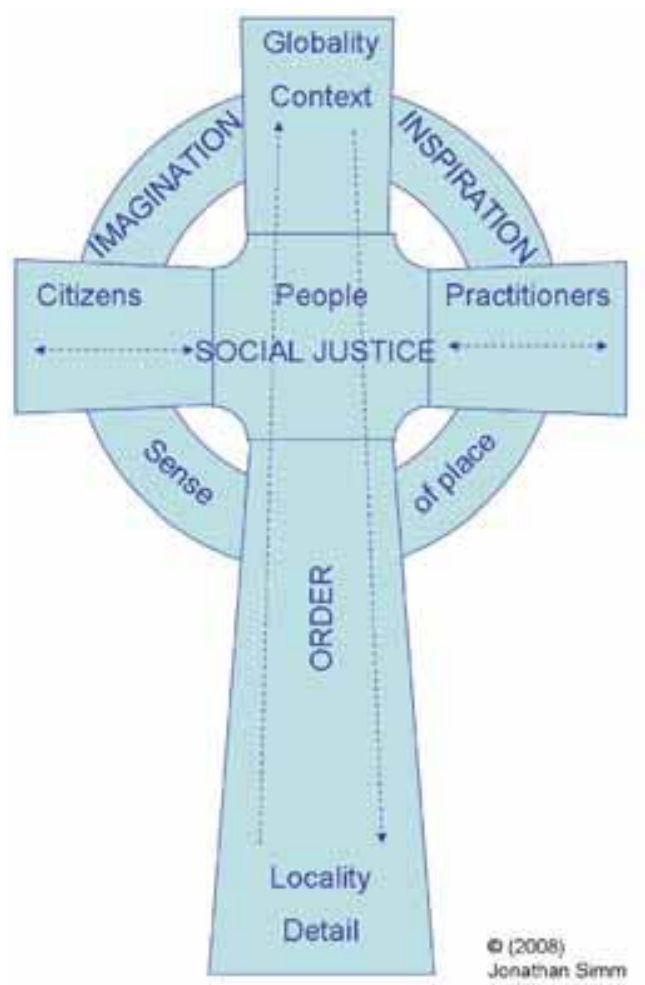

Figure 1. Model of social features of FCERM assets.

\section{EVIDENCE TO SUPPORT FRAMEWORK FOR APPLICATION TO FCERM}

Whilst it is recognised that social features and issues may not be constrained into just one of the dimensions of the above framework (see Figure 2), some good examples of the practical outworking of these factors have been derived from the author's interview data.

\subsection{Order}

Many of the engineering aspects of Order will be well-understood and accepted by readers of this paper. However, the perspective of the users of these assets on a day-to-day basis adds a different dimension.

Talking about rock groynes, one engineer said:

"I tell you what rocks are for: Sunbathing. They are massive storage heaters, they warm up ... and ... they stay warm into the evening, so you can sit on them and keep warm ...

He also commented: "What we [engineers] don't like, the people do like ... - -lighting barbecues amongst the rocks."

... groynes and outfalls and things like that are things that people like to walk out on. Whether they

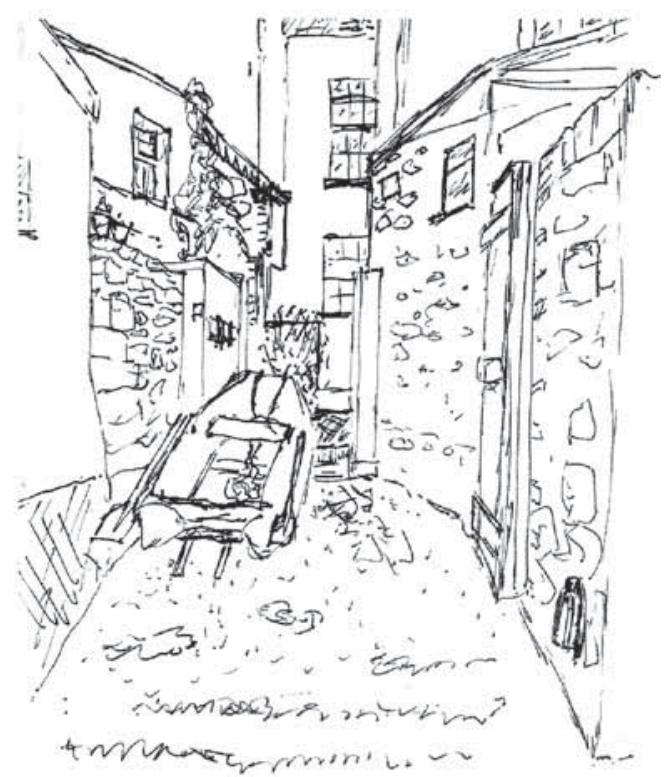

Figure 2. Sympathetically designed flood gates and walls at Lympstone, Exe Estuary, UK: demonstrating engineering order in delivering access and a consistent standard of protection, whilst showing both imagination and respect for social justice in provision of a design suitable for a picturesque village. 
should or whether they shouldn't is another matter, but they do like to walk out on them. And I mean, we're a strange nation, we like to walk out on piers and get out, don't we."

A flood plain asset manager commented:

"I was wandering round the ... flood plain just trying to get a feel for how the floodplain worked and the way the channels went and what was linked to what and I thought I was out in the middle of a farm in the middle of nowhere and suddenly some dog-walkers came up behind me and then ten minutes later someone's going the other direction and I suddenly realise I'm looking at this as a floodplain asset as some way of defending [the local town] from flooding and they're looking at that as where they exercise their dogs every day. Plus, of course forgetting that it's agricultural land, that's got, I suppose, a nine to five job as well ... grazing cattle and things."

\subsection{Inspiration}

One engineer described local perceptions of a 'historic' sea wall. A preservation order was placed on the walls on the basis that:

" 'These sea walls are the oldest in [the area] and they are a feature of [the town] and they've got these unusual features which we think are worthy of preservation and listing.' ... And this was when we were initially promoting our coast protection scheme in [the town], and they thought, probably rightly, that we were going to come along and demolish them and build some new ones. And they said you shouldn't demolish those."

Another practitioner described her approach to making a weir more attractive:

"I'd saved some great big blocks of sandstone, and ... when this scheme came along, I had just the thing. I had them transported up to this park and ... we finally got built was something that looked like an old stone weir associated with the mill channel ... it looked like a broken, old mill weir and so the water came through, over it and cascaded, sort of spread down ... And you've got bits of rubble spreading out from it so it became a cascade not a weir really. Now, that became so fascinating to the local youths that ... when it was first opened, they took it apart stone by stone, so that backfired really, but visually it was really successful. We put it back, and glued it together in some way so that it was more permanent and they didn't take it apart then. But really that sense of place, you know, I think it was important to analyse what that space meant, what that weir meant. Okay, take it apart and make it into something that's more functional and more aesthetically pleasing, and fitted the new scheme, but you have to give it back that sense of place, and we've had kids play there and, you know, there's lots of areas around that are shallower and slow moving and they can go and paddle, and we've had children planting marginal plants there when it was first opened, and community days planting trees and so on. Local schools [were] getting interested in it. They put a couple of willow sculptures up, further upstream. It was a focus for community activity at all levels for quite some time."

The importance of views of water to residents was expressed by another asset manager:

"There's one lady who lives in a house on stilts, and is happy except for the fact that she gets cut off every now and again. Obviously [her house] never floods because it's way above the flood level, but she gets cut off every now and then. She's got a supply of tinned beans and if one of her neighbours is happy to bring her fresh bread and fresh milk, and probably the newspaper, then she's fine, she can sort of holeup for a couple of weeks. And ... she'll suffer about once every ten years because the rest of the time she's got one of the nicest views in the country I think .... The biggest most expensive properties ... that we deal with are all along the river. People will pay extra for the view, as they see it, or pay extra for the flood risk, as I see it."

In contrast, he noted how that man-made or canalised channels were often rather unattractive:

"absolutely no good ecology in them and tend to just be full of litter, and so it goes the other way, where you've got the channel which is so heavily artificial, you've then got less of an amenity part to it because who wants to enjoy a walk by the river when it's got two foot of black silt in the bottom and crisp packets everywhere."

A coastal engineer commented on the importance of the apprearance of the coast:

"Yes, our coast is much photographed, much painted and much used for artistic purposes, either the natural features of the coast or the man-made features or the human activity on the coast. It's very, very strong in people's psyche in the area, and they come here specifically to photograph or paint here. See it, feel it."

\subsection{Social justice}

One incident where social justice was not given due importance was recounted by a practitioner: "We did have some really bad incidents ... for example, somebody saying to us "this clematis that's climbing up this telegraph pole at the bottom of my garden, I planted it in memory of my husband who died in the garden" ... We ... made notes of this, we'd sent reminders to this particular guy. [But] diggers went in-ripped the lot up-took the telegraph pole out. It may have been that it was the telecom people that took the post down, but the project manager hadn't attended to the detail. The woman was really upset of course. Now, how do you make that good?" 
Discussing the tension over the use of trees on banks and in water courses, an environmental assessment professional commented:

"Every time you take trees out, the assumption is that they're gone, you aren't going to be able to plant them because someone somewhere, some project manager or engineer is going to say "Well I can't prove that it's ok to plant them because the modelling won't give me that fine detail, so I'll have to play safe and not plant them." And, you know, that's not being critical of individuals, it's simply saying that it works against us, this modelling tool, in that context. But of course we are out to protect people from flooding so who's going to make that brave decision because if people flood then probably they will say "Ah, but they planted those trees." But if you look at it as a bigger picture, then overall, landscape is gradually going to deteriorate."

\section{CONCLUSIONS}

Alternative approaches to expressing the social features of FCERM assets have been explored using ideas derived from a range of disciplines including social science and geography, community psychology, architecture, landscape architecture and the built environment. No one of these specialist disciplines seemed to offer a sufficiently broad perspective to capture all the issues involved in making a link between FCERM assets and people. Broader perspectives are offered by philosophy and theology and from these a tentative framework of Order, Imagination and Justice has been identified. The dimensions of the framework are illustrated from examples drawn from interviews with practitioners.

\section{ACKNOWLEDGEMENTS}

The author wishes to acknowledge the support being received for this research through the doctoral training account of the Engineering and Physical Science Research Council. He is also indebted to the support received from supervisors Dr. M. Mawdesley, Dr. S. Seymour and Prof. C. Thorne at the University of Nottingham. The valuable information provided by interviewees and by academics during discussions is also acknowledged, including those with Prof. T. Gorringe of the University of Exeter on the theoretical framework.

\section{REFERENCES}

Alexander, C., Ishikawa, S., Silverstein, M., Jacobson, M., Fiksdahl-King, I. and Angel, S., 1978. A pattern language: towns, buildings, construction. Berkeley, CA: Oxford University Press Inc. Brice, 1995.

Alexander, C, 2002. The nature of order: an essay on the art of building and the nature of the universe. Book 1: the phenomenon of life. Berkeley CA: Centre for Environmental Structure.

Bartuska, T. 2007. The built environment: definition and scope. In McClure, W. and Bartuska, T. eds. The built environment: a collaborative enquiry into design and planning. Hoboken NJ: John Wiley \& Sons, pp. 3-14.

Brueggemann, W., 2002. The land: place as gift, promise and challenge in biblical faith (2nd Edition). Minneapolis, MN: Fortress Press.

Bryce, 1995. Symbolism of the Celtic cross. Red Wheel/ Weiser.

CABE, 2004. The value of public space: how high quality parks and public spaces create economic social and environmental value. London: CABE.

London: Checkland, P. and Scholes, J., 1990. Soft systems methodology in action. Chichester: John Wiley.

Cohen, A.P., 1985. The symbolic construction of community. London: Ellis Horwood.

Countryside Agency and Cheshire Landscape Trust, 2005. Parish landscape character assessment pilot projectfinal report: preparing parish landscape statements using the Countryside Agency/Scottish Natural Heritage Landscape Character Assessment Guidance for England and Scotland. CA \& SNH, November.

Cresswell, T., 2004. Place: a short introduction. Oxford; Blackwell.

Delanty, G., 2003. Community. London: Routledge.

ECUS (Environmental Consultancy University of Sheffield), 2003. Guidance for coastal defence in relation to their landscape and visual impacts. Bangor: Countryside Council for Wales.

Gorringe, T., 2002. A theology of the built environment: justice, empowerment, redemption. Cambridge: Cambridge University Press.

Gwilt, J. 2007. English translation of Text of Marcus Vitruvius Pollio's De Architectura, Book I downloaded on 07/06/2007 from http://penelope.uchicago.edu/Thayer/ E/Roman/Texts/Vitruvius/1*.html

Harvey, D, 1996. Justice, nature and the geography of difference. Oxford: Blackwell.

Inwood, M., 1997. Heidegger - a very short introduction. Oxford: Oxford University Press.

Latour, B., 2005. Reassembling the social: an introduction to Actor-Network-Theory. Oxford: Oxford University Press.

Liepins, R., 2000. New energies for an old idea: reworking approaches to 'community' in contemporary rural studies. Journal of Rural Studies, 16, 23-35.

Massey, D., 1997. A global sense of place. In Barnes T and Gregory, D. eds. Reading human geography; the poetics and politics of enquiry. London: Arnold, pp. 315-23. 
McMillan, D. and Chavis, D., 1986. Sense of community; a definition and theory. Journal of community psychology, 14, 6-23.

Peterson, N.A., Speer, P.W. and Hughey, J., 2006. Measuring sense of community; a methodological interpretation of the factor structure debate. Journal of Community Psychology, 34(4), 453-469.

Puddifoot, J.E., 1995. Dimensions of community identity. Journal of Community and Applied Social Psychology, 5, 357-370.

Puddifoot, J.E., 1996. Some initial considerations in the measurement of community identity. Journal of Community Psychology, 24(4), 327-336.

Roth, L., 2007. Understanding architecture: its elements, history and meaning. Boulder CO: Westview Press.

Sarason, S.B., 1974. The psychological sense of community-perspectives for community psychology. San Francisco: Jossey Bass.

Scott, A., 2002. Assessing public perception of landscape: the LANDMAP experience. Landscape Research, 27(3), 271-295.

Sennett, R., 1998. The corrosion of character: the personal consequences of work in the new capitalism. New York: Norton.

Silf, M., 2001. Sacred spaces: stations on a Celtic way. Oxford: Lion Publishing.
Simm, J. and Samuels, M, 2006. Telling good stories: engaging in dialogue with communities about flood and coastal erosion risk management in a post-modern society. Proc. 41st Defra Flood \& Coastal Management Conference, York. London: Defra.

Simm, J., Wallis, M., Sayers, P., Gouldby, B., Buijs, F., Flikweert, J.J and Hamer, B. (2006). Developing a performance-based management system for flood and coastal defence assets. Proceedings 41st Defra Flood \& Coastal Management Conference. York. London: Defra, Paper 09.10.

Spirn, A.W., 1998. The language of landscape. New Haven: Yale University Press.

Tartaglia, S., 2006. A preliminary study for a new model of sense of community. Journal of Community Psychology, 34(1), 25-36.

Tönnies, F. 1963. Community and society. Tr C. Loomis. New York: Harper.

Warburton, D., 1998. A passionate dialogue: community and sustainable development. In: Warburton, D., ed. Community and sustainable development; participation in the future. London: Earthscan, pp. 1-39.

Wickipedia, 2007. Information downloaded from http:// en.wikipedia.org/wiki/De_architectura on 07/06/2007 and validated from other Internet sources. 


\title{
Fluid thinking...smart solutions
}

HR Wallingford provides world-leading analysis, advice and support in engineering and environmental hydraulics, and in the management of water and the water environment. Created as the Hydraulics Research Station of the UK Government in 1947, the Company became a private entity in 1982, and has since operated as a independent, non profit distributing firm committed to building knowledge and solving problems, expertly and appropriately.

Today, HR Wallingford has a 50 year track record of achievement in applied research and consultancy, and a unique mix of know-how, assets and facilities, including state of the art physical modelling laboratories, a full range of computational modelling tools, and above all, expert staff with world-renowned skills and experience.

The Company has a pedigree of excellence and a tradition of innovation, which it sustains by re-investing profits from operations into programmes of strategic research and development designed to keep it - and its clients and partners - at the leading edge.

Headquartered in the UK, HR Wallingford reaches clients and partners globally through a network of offices, agents and alliances around the world.

\section{HR Wallingford}

Working with water

\author{
HR Wallingford Ltd \\ Howbery Park \\ Wallingford \\ 0xfordshire 0X10 8BA \\ UK
tel $\quad+44(0) 1491835381$
fax +44 (0)1491832233
email info@hrwallingford.co.uk

\section{www.hrwallingford.co.uk}

